on yield is carried out only on the basis of first lactation yizld. A formula is developed for computing the optimal culling rate, which is a function of the expected difference in yield between first and later lactations and of the repeatability of yield.

The mean yield of the current herd is little affected by culling. At the optimum of about 70 per cent of cows retained, the increment in yield is around I per cent, so it is likely to be more economic to bring fewer heifers into the herd and practise a minimum of culling. If a substantial genetic trend is incorporated and yield is to be maximized in later generations, the benefits of culling are greater and fewer animals should be retained after first lactation. The greatest benefits from culling are obtained if it is practised in mid-lactation.

\title{
INFLUENCE OF DIFFFERENT REPLACEMENT CONCEPTS UPON PROFITABILITY OF DAIRY CATTLE
}

\section{N. KÖUZI} Institute of animal production, Swiss Federal, Institute of Technology (E.T.H.) ZURICH
(Switzerland)

A model describing dairy herd dynamics and profitability is presented, using the following parameters: replacement rate, survival rate, calving interval, max. number of lactations. Age composition and performance are computed with the aid of these parameters. Gross margin is defined as: income from milk, surplus cows and calves, less costs for feeds and replacement females. Firstly, the effect of different replacement procedures on herd profitability is treated. Secondly, the economic consequences of changing parameter values is demonstrated. Considering genetic progress and appropriate estimation of breeding values for replacement females leads to increased genetic progress on the dam - daughter pathway. If large differences in genetic levels between herds or between strains exist, then replacement females with high genetic levels can be produced. This increases culling rates of old cows which results in a decreased herd life. The consequence is a forced replacement of old cows and therefore a decreasing average herd life.

ACTUAL SELECTION DIFFERENCES WITHIN HERD FOR NORWEGIAN RED CATTLE

\section{E. FIMALAND}

Department of Animal Genetics and Breeding, Agricultural University of Norway, As-NLH, Norway

Selection differential for the path of dam to daughter is generally small in the population of N.R.F. The selection differential increases by increasing herd production levels. The culling intensity seems to be equal for cows calving in different months.

THE INHERITANCE OF CONFORMATION TRAITS IN BRITISH FRIESIANS

\section{A. E. MCCLINTOCK, L. K. O'CONNOR}

\section{Milk Marketing Board, Thames Ditton, Surrey, England}

The Milk Marketing Board of England and Wales' AI Service progeny tests approximately I30 Friesian bulls each year in co-operating milk recorded herds. In the three years 1976,1977 and 1978 the conformation of 20,819 Friesian heifers in such herds was assessed using a 10 point scale for each character.

Nine dairy conformation traits were scored for each heifer: Head, Neck and Shoulders; Body Capacity; Top Line and Rump; Legs; Feet; Fore Udder; Rear Udder; Teat Shape; Teat Position. In addition, a beef shape score using a I to 5 scale was recorded for II,205 heifers assessed in 1978 .

A hierarchical analysis of variance was carried out and components of variance estimated for sires within herds, herds within areas, areas within regions, and regions within years. For each of the ro traits, there were significant differences between sires within herds, herds within areas, and areas within regions. Some year and region within year effects were also significant. 
Heritabilities for the nine traits were 0.38 for Head, Neck and Shoulders; 0.57 for Body Capacity; 0.39 for Top Line and Rump; 0.45 for Legs; 0.5 I for Feet; 0.44 for Fore Udder; 0.59 for Rear Udder; 0.57 for Teat Shape; 0.49 for Teat Position; 0.76 for Beef Shape. Standard errors of these heritabilities were about o.I4.

Genetic and Phenotypic Correlations between the nine traits were calculated. Standard errors of the Genetic Correlations ranged from 0.15 to 0.20 . Most of these correlations were positive but some were not significantly different from zero. Beef Shape and Body Capacity had a genetic correlation of $0.4 \mathrm{I}$.

Genetic Correlations between Beef Shape and Body Capacity, Rear Udder and Teat Position were : $0.4 \mathrm{I},-0.12,-0.14$ respectively. Methods of sire assessment for conformation are discussed in the light of these results; the BLUP approach, absorbing " herd year " effects is preferred.

BREEDING FOR MILK AND BEEF IN CATTLE-DESIGNING THE OVERALL STRATEGY

\title{
V. VILVA and U. B. LINDSTRÖM
}

\author{
Institute of Animal Breeding, Box 18 , огзот Vantaa $3 \circ$, Finland
}

A three-stage index selection programme of dual purpose bulls was studied in order to assess the significance of the selection stages and the genetic gain to be expected. In accordance with previous studies the results showed that more than 90 per cent of the economic gain comes from the milk traits. In addition the study showed that over Io per cent of the gain is due to the increased feed conversion efficiency, mainly in milk production. The study also indicated that direct selection for feed efficiency in milk production would give appreciably higher gain even if it were done on the basis of only 5 dams/bull.

BREEDING FOR MEAT AND MILK, 2. EXPERIENCES OF INDIVIDUAL, HERD MATING PLANS

\section{J. MÄKI-HOKKONEN}

\section{The Finnish Animal Breeding Association, Department of Animal Brecding, Vantaa, Finland}

In 1978 in Finland individual herd mating plans were drawn up for 4 I 80 herds including 63780 cows or heifers. This activity is carried out under the national milk-meat programme (M.M.P.) which defines the strategy and objectives of the scheme. The most positive-results of the milk meat programme have so far been :

- a more rational use of AI bulls;

- improvement of the young sire sampling routine;

- increased farmer interest and participation in AI breeding work.

The relatively small portion of the national herd which is milk-recorded ( 35 per cent) and the small average herd size are the main obstacles in the implementation of the scheme. The supply and quality of beef bulls in AI will need constant attention in future to ensure satisfactory results from the crossing of dairy cows with beef bulls.

\section{A COMPUTER MATING SERVICE ESTABLISHED BY A CATTLE HERDBOOK SOCIETY}

\section{J. A. P. CHARDON}

\section{The Nethcrlands Catlle Herdbook Society, the Hague, Netherlands}

In $197^{8}$ a computer mating service was started byt he Netherlands Cattle Herdbook Society (N.R.S.). Because the A.I. Cooperatives are relatively small it is logical that the programme was started by N.R.S. Three sources of information on the cows are used $: \mathrm{r}$. the milkrecording and pedigree data, 2. the management traits given by the breeder and 3 . the type traits evaluated by the N.R.S. classifier. A computerized printout showing each cow and her evaluation plus her four best bull prospects are being sent to the breeder twice a year. 